DOI 10.37882/2500-3682.2020.10.05

\title{
ТРАГИКОМЕДИЯ Т. МИННУЛЛИНА “ОБЕТ” НА ТЕАТРАЛЬНОЙ СЦЕНЕ
}

\section{"THE VOW"TRAGICOMEDY BY \\ T. MINNULLIN ON THE THEATRE STAGE \\ A. Zakirzyanov}

Summary: This article analyses "The vow" play by Tufan Minnullin, which was staged in Kazan in K. Tinchurin theatre. At the junction of centuries, the author was one of the leading authors, who defined the peculiarities of tatar literary drama development. In the tragicomedy "The vow", which occurred one of T. Minnullin's last works, the author reveals constant philosophical and moral questions of being. According to the stage incarnation and analysis of the play, the aim of the article is to show artistic and aesthetic finds of the author, the director's concept of reporting the main idea to the audience, and revealing the peculiarities of artistic searches, which can be seen in the actors' playing. The full and detailed analyses help to see the ways of artistic searchers in modern tatar drama literature and theatre.

Keywords: tatar theatre; Tufan Minnullin; play; interpretation; actor; idea; image.
Закирзянов Альфат Магсумзянович

Д.филол.н., доцент, ГУ «Институт языка, литературы и искусства имени Г. Ибрагимова» Академии наук Республики Татарстан (2. Казань) Alfat_zak@mail.ru

Аннотация: В статье анализируется спектакль, поставленный в Казани на сцене театра им. К. Тинчурина по пьесе Т. Миннуллина "Нәзер" / "Обет". На стыке веков драматург был одним из ведущих авторов в области татарской сценической литературы, во многом определившим особенности процесса её развития. В трагикомедии "Обет", ставшей одним из последних его произведений, драматург обращается к непреходящим философским и нравственным вопросам бытия. Целью является, исходя из анализа и оценки сценического воплощения спектакля "Обет", определение художественноэстетических находок драматурга, раскрытие режиссерской концепции донесения основной идеи до зрителя и выявление своеобразия творческих поисков, отраженных в игре артистов. Обстоятельный анализ и оценка данного спектакля позволит также выявить пути творческих поисков в современной татарской драматургии и театре.

Ключевые слова: татарский театр; Туфан Миннуллин; спектакль; интерпретация; артист; идея; образ.

сильных духом, ярких и оригинальных национальных героев, поиску новых путей, изобразительных средств и приемов раскрытия их перед своими зрителями и читателями. Многочисленные произведения драматурга, в частности, "Ай булмаса йолдыз бар"/ "Когда нет луны, то есть звезды” (1974), “Әлдермештән Әлмәндәр” /“Альмандар из Альдермыша" (1975), “Әниләр һәм бәбиләр"/ “Мамы и младенцы” (1982), “Моңлы бер жыр" / “Грустная песня" (1984), “Шәжәрә" / "Родословная" (1994), "Саташу” / "Сумасшествие" (2001), "Мулла" / "Священнослужитель" (2006), "Төш" / "Сон" (2010) и другие пьесы с успехом были поставлены в России и за рубежом на сцене театров братских тюркских народов [2, с. 218]. Одним из особенностей этих произведений является "рассмотрение понятия судьбы как некой цепи событий и перемен, родившихся вследствие активности культурных сил, наравне с понятиями будущего и исторического прошлого" [5, с. 97]. Ставшая одним из последних произведений литератора трагикомедия "Нәзер"/ "Обет" (2010), поставленная в Оренбурге, в Нижнекамске и в Казани, снискала любовь зрителей. Спектакль, поставленный на сцене театра им. К. Тинчурина, в жизни республики обрел звучание значительного культурного события. С одной стороны, эта постановка помогает как бы проникнуть внутрь и осознать особенности творчества Т.Миннуллина, то, с другой стороны, она позволяет определить пути художественного поиска, идущего в татарских театрах. Основной целью 
данной статьи является, определение художественноэстетических находок драматурга, раскрытие режиссерской концепции донесения основной идеи до зрителя и, опираясь на методы анализа и оценки сценического воплощения спектакля "Обет", выявление своеобразия творческих поисков, отраженных в игре артистов. В связи с этим выделяются задачи определить: жанровое своеобразие драматического текста и его отражение в изобразительных средствах и приемах; особенности донесения заложенной в содержание пьесы идейноэстетической мысли до зрителя (в результате анализа деятельности режиссера и игры артистов); эстетические и стилевые отличия, присущие театру им. К.Тинчурина.

\section{Методы исследования}

Наше исследование опирается на выработанные отечественной наукой методы анализа театрального искусства, в частности, спектакля. Исходя из поставленной цели были использованы культурно-исторический, проблемно-тематический и системный методы изучения искусства, в совокупности позволяющие воспринимать спектакль в единстве формальных и содержательных компонентов, интерпретировать его как часть культурно-исторической действительности.

\section{Обсужление и результаты}

В течение сезона 2019-2020 года Татарский государственный театр им. К.Тинчурина порадовал своих зрителей премьерами нескольких спектаклей. Среди них особый успех снискал спектакль, поставленный по пьесе Т.Миннуллина "Обет", неизменно идущий с аншлагом. Режиссер спектакля - Зиннур Сулейманов, художник - Анастасия Шамова, композитор и аранжировщик - Нияз Валиев, хореографы - Ренат и Татьяна Мифтаховы, а песни написала актриса Зульфия Валиева. 3. Сулейманов - режиссер, который живет и творит в Республике Башкортостан. Его свойства истинного профессионала проявляются в искренней любви к театру, артистам, зрителям, в посвящении своего таланта без остатка искусству, в умении не только руководить артистами, но и сформировать из них команду своих единомышленников. Он завоевал всеобщее признание тем, что помимо артистов легко находит общий язык со всеми, кто участвует в подготовке спектакля, выслушивает мнение других, а самое главное, одобрительно относясь к желаниям и стремлениям каждого, приветствуя и поощряя личную инициативу, умеет мастерски направлять их в нужное русло. Режиссерские находки 3. Сулейманова в ходе поиска новых приемов донесения идей и мыслей Т. Миннуллина до каждого зрителя свидетельствуют о его тонком художественном вкусе, мастерском оперировании авторским текстом и отличном владении секретами сценического искусства.

Спектакль, поставленный по трагикомедии Т. Мин- нуллина "Обет", привлекает внимание истинно народным духом, поучительными жизненными событиями, отражающими татарский дух и национальное бытие. В основу сюжета заложено следующее событие: деревенские парни Хисматулла и Хикматулла, выросшие по соседству, женятся в один и тот же день, а вскоре уходят на войну. Беспощадный молох войны, явная угроза гибели толкают парней на довольно странный шаг. Они принимают обет: "если оба вернемся живыми, то поменяемся женами.(...)Не навсегда, а только на неделю". Оказывается, Хикматулле его ясновидящая бабушка сказала: "коли даешь обет, то пока не выполнишь его, жизнь твоя не оборвется". Желание выжить в той чудовищной бойне столь велико, что Хикматулле очень хочется верить в силу данного обета: "Может и наша жизнь не оборвется. Может, живыми вернемся в деревню". Парни выжили на войне, однако впереди их ждет судьба, полная поучительных событий, одновременно и горькая, и сладкая...

Т. Миннуллин обращается к известной литературной форме, используемой им во многих произведениях: один из участников, намекая на будущие события, по ходу действия дает некоторые комментарии. Что в свою очередь усиливает жизненность происходящих событий и явлений, поэтому зрители воспринимают их как реальные, волнуются и переживают за судьбу героев.

В спектакле участвует всего четверо героев: Магира (Гульчачак Хафизова), Загира (Зульфия Валиева), Хисматулла (Рустем Гайзуллин), Хикматулла (Ирек Хафизов). Но ведь это какие герои, мало того, что автор наделяет каждого из них особым характером, ярким качеством, отличающим его от остальных, так в свою очередь и артисты создают чрезвычайно поучительные, неповторимые образы. В первом действии перед зрителями предстают вполне обычные деревенские парни и девушки. Парни вроде бы даже слегка похожи друг на друга, да и характерами особо не различаются, пока только наряды девушек и их кокетливые жесты непохожи меж собой. В противоречивых событиях последующих актов, конечно же, то или иное качество каждого из них проявится наиболее выпуклым образом.

Вернувшийся с войны живым и невредимым Хисматулла довольно сильно изменился, даже постарел как будто. Герой Р. Гайзуллина сдержанный, спокойный, тяготы войны умерили его пыл. Однако деревенская простота никуда не делась - даже не задумываясь о последствиях, он рассказывает жене об обете, который они дали с Хикматуллой, пытаясь объяснить смысл их странного шага. А вот Магира в исполнении Г. Хафизовой раскрывается всей своей женской сутью - отчаянная, решительная и очень темпераментная. Её движения энергичны, взгляд излучает любовь, в ней сквозит желание обнять и приласкать мужа. Женщина, которая некогда признавалась в своей излишней стеснительности, говоря, что в юности 
“даже от пристального взгляда парней мне становилось щекотно", теперь со словами "вот ведь, мой костер, тлевший четыре года, вдруг вспыхнул", падает в объятия мужа. Момент прихода Загиры к ним, чтобы повидаться с Хисматуллой и расспросить его о своем муже, напоминает картину столкновения огня и воды. Истосковавшаяся по мужу Магира вне себя от счастья встречи с ним, а героиня 3.Валиевой не в силах скрыть душевную боль, вызванную сумятицей чувств, где перемешались тоска, страхи, ожидание и стремление сохранить хотя бы проблески надежды на возвращение мужа. Режиссер и артисты, очень тонко уловив черты женской психологии, характерные действия и поступки, в отдельные моменты не подчиняющиеся никакой логике, вниманию зрителя предлагают эмоционально насыщенный эпизод, позволяющий в переживаниях героев ощутить горечь войны и боль утрат.

С возвращением в деревню Хикматуллы спустя десять лет после окончания войны события ускоряются, внутренний конфликт нарастает. Он, оказавшись во вражеском плену, сначала терпит страдания и муки в немецких концлагерях, а после войны его отправляют в лагерь, расположенный на золотых приисках вблизи Магадана. Хикматулла, сильно исхудавший и больной, еле добирается до своей деревни. Герой Ирека Хафизова раскрывается как вконец изможденный, потерявший вкус к жизни человек. В игре артиста, его отрывистых репликах сквозит злость на советскую систему, обида и сожаление за напрасно прошедшие годы молодости, чувство горечи от потерянного здоровья. В эти мгновения И. Хафизов будто и не играет роль, а перевоплощается в своего героя, поэтому зритель потрясенно слушает его слова, обращенные к жене Загире с безмерной жалостью: “Ты единственная красавица в этом мире, а счастья у тебя нет".

Хотя прошло довольно много времени, однако Хикматулле не удается поправить здоровье, и его жена Загира вянет на глазах. И Хисматулла, живущий по соседству, ослабнув здоровьем, валится с ног. Именно тогда Магира вспоминает о давнем обете, данном мужчинами. Гадалка из села Барыш причину всех болезней видит в неисполнении обета. Любящая жена и мать шестерых детей Магира требует выполнения обета. И мужчины вынуждены на неделю поменяться женами... Именно в этот момент и раскрывается трагикомическая суть спектакля. На одной чаше весов, угроза потерять мужей, желание во что бы то ни стало вернуть им здоровье, а на другой по собственной воле уложить своего мужа в постель с другой женщиной... Блестяще показывая, насколько это болезненно и трудно особенно для женщин, артисты заставляют зрителей испытывать то сильное потрясение, то смеяться от души. В народе не зря бытует выражение "мужа отдавать, что душу отдавать". К тому же, еще надо вынести и бремя стыда перед односельчанами.
Кульминацией событий в спектакле становится разговор-объяснение мужей с женами друг друга. Загира в исполнении 3.Валиевой, играющей роль женщины, не познавшей вдоволь мужской ласки, перед зрителями раскрывается совершенно иной. Её девичьи чувства к Хисматулле вспыхивают вновь, она ощущает себя настоящей женщиной, и не в силах совладать с бурными порывами, она истово любит и вызывает ответную любовь. Показать подобную картину зрителю, конечно, задача не из легких, поскольку помимо жизненности она должна служить отражением чистых и незапятнанных чувств, не имеющих ничего общего с бесстыдством. Своим темпераментом и актёр Р.Гайзуллин завоевал аплодисменты зрителей. Манера держаться и речь артиста сами по себе раскрывают характер героя. Природа одарила его силой и темпераментом, однако он хорошо понимает, что должен вести себя в рамках определенных морально-этических правил. Глубоко понимая душевное состояние своих героев, 3. Валиева и Р. Гайзуллин рождают пример сохранения человечности и искренности во взаимоотношениях даже в этих условиях. Режиссер, художник, хореограф, мастер по свету на высоком профессиональном уровне отобразили акт подчинения великому инстинкту, подаренному человеку природой, движением белых теней за завесой, символизируя чистоту и наслаждения.

Встреча Магиры и Хикматуллы еще более пронзительна. Между ними есть взаимное притяжение и близость, они и не скрывают этого. Под действием пробудившихся чувств, Хикматулла распахивает душу перед ней: "Любил я тебя, Магира. До смерти любил. Ведь сколько раз признавался,но ты не поняла меня. Кроме Хисматуллы никого не видела и не слышала. Любил я. Хотел было перейти вам дорогу, но ведь и Хисматулла был моим другом". Исповедуясь перед Магирой, мужчина осознает, что именно чувство любви, желание пообщаться с близкими людьми придают ему сил и вселяют уверенность. За ту самую неделю герой И. Хафизова претерпевает разительные духовные перемены. Артист своей игрой убедительно раскрывает состояние человека, впервые познавшего, что на свете есть женщина, всей душой понимающая и чувствующая его. С одной стороны, это как бы умиротворяет его, а с другой стороны, будучи больным человеком, он не желает стать обузой для своих близких и уходит из дома. Затем сообщается о трагической смерти Хикматуллы. Печальная участь героя И.Хафизова звучит как укор бедствиям войны, сталинскому режиму и несправедливому обществу.

В последнем действии, узнав о беременности Загиры, инициативу в свои руки берет Магира и решает все по уму-разуму: "Нам придется делить Хисматуллу меж собой. Не сердись, Загира, я не могу отдать его насовсем. Мне еще самой хочется спать в мужских объятиях. Тебе тоже хочется, наверное. Ты ведь толком так и не по- 
знала женское счастье. Хисматуллы, слава Богу, хватит нам обеим. Вон сидит, облизывается, как масляный кот. Вот выведет меня из себя, прогоню его к тебе. Пусть не шастает тайком по задворкам. Посреди бела дня через калитку войдет в твой дом. Согласна со мной? Что же ты плачешь? Не плачь, я же не плачу. Думаешь, мне легко". Зрители же, то огорчаясь, то радуясь следят за разборкой между женщинами, а потом видя, к чему идет дело, можно сказать, облегченно вздыхают. Без сомнения, эта поучительная история послужит поводом для многих по-новому взглянуть на свою жизнь, крепко задуматься о страннностях бытия. Спектакль завоевал симпатии зрителей динамичной игрой артистов, жизненностью явлений, эпизодов и мизансцен, поставленных режиссером, прекрасным музыкальным сопровождением, изяществом танцевальных движений. За событиями, где тесно переплелись трагичные и комичные явления, раскрываются нравственные и философские ценности, лежащие на иной, еще незнакомой плоскости, что и побуждает зрителей к размышлениям и спорам о жизненных коллизиях и игре артистов в этом спектакле.

\section{Зак^ючение}

Проанализировав спектакль, поставленный театром им. К.Тинчурина по пьесе Т.Миннуллина "Обет", можно прийти к следующим выводам: 1) драматург посредством чрезвычайно поучительных событий и явлений обращается к серьезным нравственным и философским вопросам бытия; 2) относительно драматического текста в спектакле можно отметить, что в событиях доминирует реализм, весьма удачно переплетающийся с мелодраматическими приемами; что в свою очередь значительно усиливает сентиментальность, чувственность, романтическую образность; 3) с помощью синтеза комедийных и трагических жанров режиссер добивается более глубокого раскрытия философского содержания и воздействия на зрителя; 4) в этом спектакле игра артистов, творческие поиски художника и хореографа, сплавляясь воедино, служат познанию ценностей общечеловеческого бытия.

\section{ЛИТЕРАТУРА}

1. Загидуллина Д.Ф. Татарская литература и национальный театр: одна дорога на двоих // Театр XXI века и вызовы времени: материалы международной научно-практической конференции, посвященной 110-летию татарского театра / под ред. Э.М. Галимовой. Казань: ИЯЛИ, 2016. С. 4-13.

2. Закирзянов А.М., Хабутдинова М.М. Новое прочтение женской темы в спектакле “Без луны, звезда нам светит” по одноименной пьесе Т. Миннуллина (2015) (реж. Р.Р. Фазлыев) // Филология и культура. Philology and Culture. 2016. № 1 (43). С. 217-220.

3. Зливко С.Д., Магсумов Т.А., Максимов Я.А. Кодификация узуальных и речевых особенностей употребления иноязычных неологизмов // Современные исследования социальных проблем. 2018. Т. 10. № 3-3. С. 151-159.

4. Магсумов Т.А. Культурно-образовательная среда провинциального города в фокусе локальной истории: по страницам работ сочинских краеведов // В мире научных открытий. 2013. № 11 (47). С. 143-149.

5. Шамсутова А.А. Мифологема Судьбы в пьесах Т.Миннуллина // Новые тенденции в развитии современной татарской литературы. Казань: Татар. кн. издBo, 2010. C.90-99.

6. Magsumov T.A. Periodicals as a source on the history of secondary vocational schools of late imperial Russia // Журнал министерства народного просвещения. 2014. № 1 (1). C. 12-20. 